\title{
DFT/TDDFT Investigation on the Electronic Structure and Spectroscopic Properties of Cis-Dioxomolybdenum (VI) Complexes
}

\author{
Imane Seghir, Nadia Nebbache, ${ }^{\star}$ Yazid Meftah, Salah Eddine Hachani \\ and Samira Maou \\ Laboratory of Applied chemistry LCA, Faculty of Sciences, University of Biskra, \\ B.P. 145, R.P. 07000 Biskra, Algeria \\ *Corresponding author: E-mail: nadianebbache1@gmail.com; nadia_nebbache@yahoo.fr \\ Telephone/Fax: (+213)33543318
}

Received: 02-11-2019

\begin{abstract}
In this contribution, two mononuclear molybdenum complexes with $\mathrm{H}_{2} \mathrm{~L}$ tridentate (ONO) Schiff base ligand are characterized using computational techniques. Density functional theory (DFT) and its time extension (TD-DFT) calculations are performed to study the electronic structure in ground and excited state and to interpret the electronic absorption spectra in gas and aqueous phases. TDDFT calculations affirm that the LMCT charge transfer dominates for both complexes and a hypochromic effect on absorption properties is observed according to solvent substitution. All theoretical results compare nicely with available experimental data.
\end{abstract}

Keywords: Mo complexes; schiff base; electronic absorption spectra; DFT; TD-DFT

\section{Introduction}

Transition metal complexes have attracted considerable attention in the development of coordination chemistry; due to their high stability and their important properties in different oxidation state. ${ }^{1-3}$ These inorganic compounds exhibit a broad range of antiviral, ${ }^{4}$ antibacterial, ${ }^{5-8}$ antifungal agents, ${ }^{9}$ anti-inflammatory activities, ${ }^{10}$ transporting layer in organic light-emitting diodes ${ }^{11}$ and hold promise to be used in various chemical and physical fields. The interest on the mentioned compounds increases during the last two decades, particularly for complexes containing functional groups with lone electron pairs such as studied Schiff base molybdenum complexes. ${ }^{12-14}$

Molybdenum complexes with general formula $\left[\mathrm{MoO}_{2}\left(\mathrm{H}_{2} \mathrm{~L}\right)\right]^{15-17}$ are used for their excellent properties as a stimulator in the enzymatic reactions. ${ }^{18,19}$ According to two studies (Rayati et al and Jain et al.), ${ }^{20,21}$ molybdenum complexes with $\mathrm{O}$ and $\mathrm{N}$ donor ligands are seen as very strong and potential catalysts for both homogeneous and heterogeneous reactions. They are also used in some industrial processes such as epoxidation of olefins and ammoxidation of propene. ${ }^{22}$
In fact, laboratory techniques, such as spectroscopic analysis, are used to understand the properties of metal complexes but these techniques are expensive, time-consuming, and in some cases not convincing to explain some molecular phenomena. Resort to theoretical chemistry, Density Functional Theory (DFT) and its time dependent extension, Time-Dependent Density Functional Theory (TD-DFT) are very solicited due to their ability to give accurate results of the electronic structures and molecular properties. $^{23}$

In a recent research, two types of mononuclear metallic complexes $\left[\mathrm{MoO}_{2}(\mathrm{~L})\left(\mathrm{H}_{2} \mathrm{O}\right)\right]$ and $\left[\mathrm{MoO}_{2}(\mathrm{~L})(\mathrm{MeOH})\right]$ containing $\mathrm{L}$ tridentate (ONO) Schiff base ligand, where $\mathrm{L}$ $\left(\mathrm{H}_{2} \mathrm{~L}\right)=2$,4-dihydroxybenzaldehyde and benzoylhydrazone, were synthesized. They were characterized using various spectroscopic and structural techniques including UVVis, FTIR and XRD and an octahedral structural arrangement was observed. The electrochemical properties of the resulting metal complexes have been investigated by using cyclic voltammetry measurements. ${ }^{24}$

Although all their important experimental results of these complexes were reported, no theoretical background has been proposed yet to provide supplementary insights for the experimental data. 
The current contribution represents a theoretical study of structural, electronic and spectroscopic properties of these two complexes by using quantum calculations based on DFT and TDDFT approaches.

\section{Computational Details}

The ground state geometry of molybdenum complexes was fully optimized using density functional theory (DFT) calculations ${ }^{25-28}$ based on CAM-B3LYP exchange-correlation functional ${ }^{29}$ with the double- $\zeta$ quality basis set LANL2DZ ${ }^{30,31}$ associated to a pseudopotential on Mo atom. The 6-311G basis set $^{32,33}$ was used for $\mathrm{N}, \mathrm{C}, \mathrm{O}$, and $\mathrm{H}$ atoms. The electronic absorption spectra were simulated by using time-dependent density functional theory
$(\mathrm{TD}-\mathrm{DFT})^{34}$ in gas and aqueous phase combined with polarized continuum model (PCM) ${ }^{35}$. The CAM-B3LYP exchange-correlation functional is known, because of its long-range corrections, to be well adapted to the calculations of charge-transfer spectra in complexes. All DFT/ TDDFT calculations were performed using GAUSSIAN 09 Rev: D.01 program package. ${ }^{36}$

\section{Results and Discussion}

\section{1. Optimized Geometry}

$\mathrm{X}$ rays diffraction $(\mathrm{XRD})$ data of the molybdenum complexes revealed that the studied systems have a distorted octahedral geometry with ONO deprotonated ligand via two phenolic oxygen and iminic nitrogen atoms. The
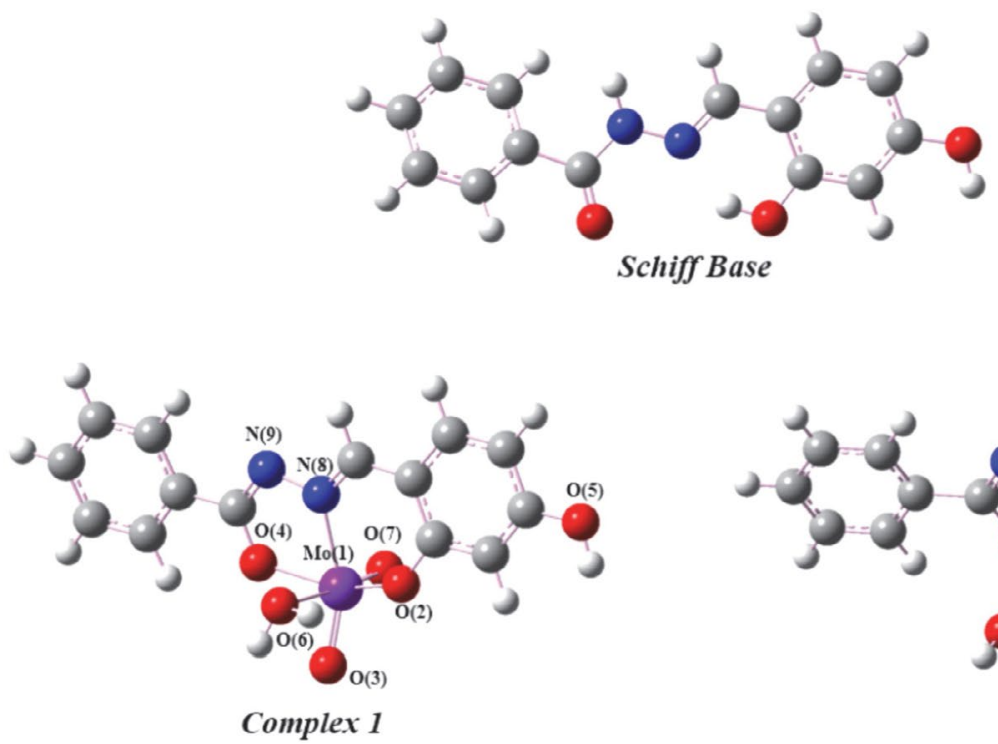

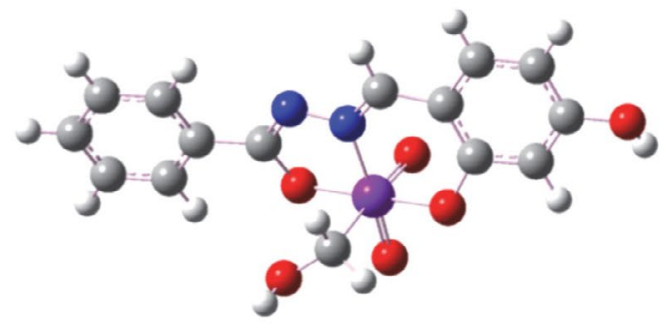

Complex 2

Figure 1. Optimized molecular structures of Schiff base and the two Mo complexes at CAM-B3LYP/LANL2DZ/6-311G* level

Table 1. Selected experimental and theoretical geometric parameters at CAM-B3LYP/LANL2DZ/6-311G* level of complex 1.

\begin{tabular}{|c|c|c|c|c|c|}
\hline \multirow[t]{2}{*}{ Bond length $\left(\mathrm{A}^{\circ}\right)$} & \multicolumn{5}{|c|}{ Angle $\left({ }^{\circ}\right)$} \\
\hline & Theo & $\operatorname{Exp}^{24}$ & & Theo & $\operatorname{Exp}^{24}$ \\
\hline $\operatorname{Mo}(1)-O(3)$ & $1.711(0)$ & 1.7162 & $\mathrm{O}(2)-\mathrm{Mo}(1)-\mathrm{O}(4)$ & $145.21(5)$ & 150.058 \\
\hline $\operatorname{Mo}(1)-O(7)$ & $1.694(3)$ & 1.6842 & $\mathrm{O}(3)-\mathrm{Mo}(1)-\mathrm{N}(8)$ & $152.77(2)$ & 155.208 \\
\hline $\operatorname{Mo}(1)-O(6)$ & $2.488(2)$ & 2.3782 & $\mathrm{O}(6)-\mathrm{Mo}(1)-\mathrm{O}(7)$ & $173.88(5)$ & 173.589 \\
\hline $\operatorname{Mo}(1)-O(4)$ & $2.001(6)$ & 2.0082 & $\mathrm{O}(3)-\mathrm{Mo}(1)-\mathrm{O}(7)$ & $107.46(6)$ & 105.539 \\
\hline $\operatorname{Mo}(1)-O(2)$ & $1.976(3)$ & 1.9202 & $\mathrm{O}(4)-\mathrm{Mo}(1)-\mathrm{N}(8)$ & $70.80(6)$ & 71.307 \\
\hline $\operatorname{Mo}(1)-N(8)$ & $2.250(6)$ & 2.2402 & $\mathrm{O}(3)-\mathrm{Mo}(1)-\mathrm{O}(4)$ & $96.48(1)$ & 96.848 \\
\hline $\mathrm{N}(8)-\mathrm{N}(9)$ & $1.379(6)$ & 1.4033 & $\mathrm{O}(2)-\mathrm{Mo}(1)-\mathrm{O}(3)$ & $101.35(5)$ & 103.768 \\
\hline $\mathrm{N}(9)-\mathrm{C}(11)$ & $1.289(2)$ & 1.3093 & $\mathrm{O}(2)-\mathrm{Mo}(1)-\mathrm{N}(8)$ & $79.98(3)$ & 83.278 \\
\hline$N(8)-C(16)$ & $1.285(4)$ & 1.2823 & $\mathrm{O}(4)-\mathrm{Mo}(1)-\mathrm{O}(6)$ & $78.86(2)$ & 97.608 \\
\hline $\mathrm{O}(4)-\mathrm{C}(11)$ & $1.319(2)$ & 1.3213 & $\mathrm{O}(4)-\mathrm{Mo}(1)-\mathrm{O}(7)$ & $101.79(8)$ & 96.691 \\
\hline $\mathrm{O}(2)-\mathrm{C}(12)$ & $1.330(6)$ & 1.3503 & $\mathrm{O}(7)-\mathrm{Mo}(1)-\mathrm{N}(8)$ & 98.82(9) & 97.608 \\
\hline$C(12)-C(15)$ & $1.409(9)$ & 1.4113 & $\mathrm{O}(2)-\mathrm{Mo}(1)-\mathrm{O}(7)$ & $100.95(6)$ & 98.431 \\
\hline$C(15)-C(16)$ & $1.434(6)$ & 1.4223 & $\mathrm{O}(3)-\mathrm{Mo}(1)-\mathrm{O}(6)$ & $78.41(0)$ & 79.957 \\
\hline$C(10)-C(11)$ & $1.473(2)$ & 1.4583 & $\mathrm{O}(6)-\mathrm{Mo}(1)-\mathrm{N}(8)$ & $75.57(2)$ & 76.497 \\
\hline
\end{tabular}


optimized ground state geometries of complex 1, complex 2 and Schiff base ligand at CAM-B3LYP level of theory are shown in Figure 1. The main optimized geometry parameters associated to the complex 1 are collected in Table 1 (complex 2 calculated structural parameters are given in supporting information file). It can be seen that the optimized structure parameters are generally in good agreement with the available experimental data. ${ }^{24}$ Slight differences between the calculated bond lengths and angles values and those given by the refinement of $\mathrm{X}$-ray results are observed, these differences are within $0.02 \mathrm{~A}^{\circ}$ for bands and $2.1^{\circ}$ for angles, respectively. This discrepancy may be partially assigned to the neglect of lattice interactions during DFT calculations. The largest difference occurs for $\mathrm{O}(4)-\mathrm{Mo}(1)-\mathrm{O}(6)$ angle which differs by $18^{\circ}$ with the experimental value, a discrepancy probably due to the effect of neighboring molecules.

\section{2. Frontier Molecular Orbitals Analysis}

Frontier molecular orbitals (FMO) have an important role for giving an insight into the chemical reactivities and some of the physical properties. The spectral properties of transition metal complexes are strongly related to the energy of these orbitals. According to Fukui's theory, ${ }^{37,38}$ the reactivity of the complexes can be estimated using the energy gap $\left(\Delta \mathrm{E}_{\mathrm{H}-\mathrm{L}}\right)$, the highest occupied molecular orbital (HOMO) could act as an electron donor while lowest unoccupied molecular orbital (LUMO) could be an electron acceptor, knowing that when the corresponding energy gap decreases, the reactivity of the complex increases and vice versa. The DFT molecular orbital diagram corresponding to the studied complexes are shown in Figure 2. It can be seen from this Figure that the energy gap of complex $1(5.89 \mathrm{eV})$ is considerably higher than the energy gap of complex $2(2.83 \mathrm{eV})$, which indicates that the complex 2 is more reactive compared to the complex 1.

The contribution rate values of Mo central atom and the ligands are given in Table 2. The HOMO eigenvalue decreases from $-7.43 \mathrm{eV}$ in complex 1 to $-11.22 \mathrm{eV}$ in complex 2 . The HOMO orbitals are mainly localized on ligands. The value of the contribution for non-metal atoms in HOMO, HOMO- 1 and HOMO-2 are between $98 \%$ and $100 \%$ in complex 1 and between $89 \%$ and $100 \%$ in complex 2 . These results predict that the electronic transitions are predominantly occurred via a ligand-metal charge transfer (LMCT).

Furthermore, the difference between LUMO and LUMO+1 is of $0.26 \mathrm{eV}$ in complex 1 , suggesting that $\mathrm{LUMO}+1$ can also easily contribute to electronic transition between HOMO and LUMO+1 whereas in the complex 2, the energy difference between LUMO and LUMO+1 is about of $3.04 \mathrm{eV}$, which confirms that LUMO+1 can't participate in the electronic transfer.

\section{3. Absorption Properties}

The electronic transitions in metal complexes involve electron transfer between metal atom and ligands. If the transfer occurs from ligand to the metal, the transition is called a ligand-to-metal charge-transfer (LMCT). If the electronic charge shifts from the ligand to another ligand, the transition is named ligand-to-ligand charge-transfer (LLCT). Intra ligand charge transfer (ILCT) arises from the transfer of electrons in the same ligand.

Table 2. Energy and composition of some selected MOs of Mo complexes.

\begin{tabular}{llcccc}
\hline & MO & Energy (eV) & \multicolumn{3}{c}{ \% of composition } \\
& & & Mo & Oxo & Schiff base \\
\hline & LUMO+3 & -0.51 & 43 & 14 & 43 \\
& LUMO+2 & -0.78 & 48 & 21 & 31 \\
Complex 1 & LUMO+1 & -1.21 & 66 & 18 & 16 \\
& HOMO & -1.56 & 35 & 44 & 21 \\
& HOMO-1 & -7.43 & 0 & 0 & 100 \\
& HOMO-2 & -8.44 & 0 & 2 & 98 \\
& HOMO-3 & -8.58 & 0 & 0 & 100 \\
& HOMO-4 & -9.26 & 0 & 1 & 99 \\
& LUMO+3 & -4.38 & 0 & 19 & 81 \\
\hline LUMO+2 & -4.79 & 36 & 17 & 47 \\
& LUMO+1 & -5.33 & 66 & 21 & 13 \\
& LUMO & -8.38 & 24 & 16 & 60 \\
HOMO & -11.22 & 2 & 11 & 87 \\
& HOMO-1 & -11.68 & 2 & 9 & 89 \\
& HOMO-2 & -12.00 & 0 & 0 & 100 \\
& HOMO-3 & -12.31 & 1 & 6 & 93 \\
& HOMO-4 & -12.84 & 0 & 3 & 96 \\
& & & 1 & 38 & 61 \\
\hline
\end{tabular}




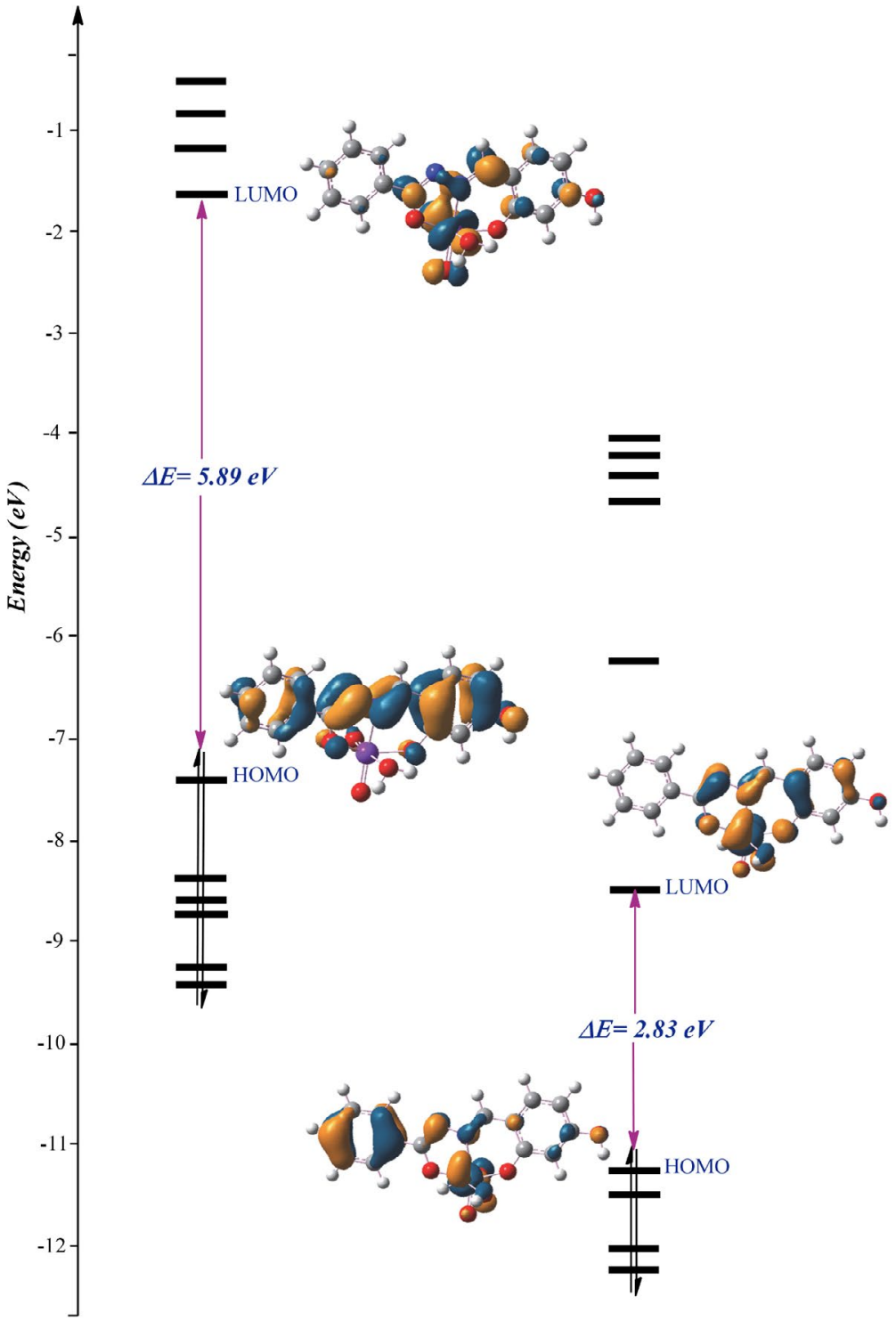

Figure 2. Frontier molecular orbital (FMO) diagram of complex 1 (left) and complex 2 (right)

Table 3. The experimental and theoretical electronic absorption wavelengths and important contributions for Mo complexes.

\begin{tabular}{|c|c|c|c|c|c|c|}
\hline & $\lambda_{\operatorname{Exp}}^{24}(\mathrm{~nm})$ & $\mathbf{l}_{\text {Theo }}(\mathrm{nm})$ & $\operatorname{Energy}(e V)$ & f & Important contributions & Nature \\
\hline \multirow{4}{*}{$\frac{\vec{u}}{\frac{\vec{d}}{a}}$} & 418 & 402.34 & 3.08 & 0.23 & $\mathrm{H} \rightarrow \mathrm{L}(89.78 \%)$ & LMCT/LLCT/ILCT \\
\hline & 329 & 323.36 & 3.83 & 0.14 & $\mathrm{H} \rightarrow \mathrm{L}+1(85.34 \%)$ & LMCT/LLCT/ILCT \\
\hline & \multirow[t]{2}{*}{304} & 301.30 & 4.11 & 0.64 & $\begin{array}{l}\mathrm{H}-1 \rightarrow \mathrm{L}(40.98 \%) \\
\mathrm{H} \rightarrow \mathrm{L}+2(40.41 \%)\end{array}$ & $\begin{array}{l}\text { LMCT/LLCT/ILCT } \\
\text { LMCT/LLCT/ILCT }\end{array}$ \\
\hline & & 251.58 & 4.92 & 0.17 & $\begin{array}{c}\mathrm{H}-2 \rightarrow \mathrm{L}(27.49 \%) \\
\mathrm{H}-1 \rightarrow \mathrm{L}+2(21.86 \%)\end{array}$ & $\begin{array}{l}\text { LMCT/LLCT/ILCT } \\
\text { LMCT/LLCT/ILCT }\end{array}$ \\
\hline \multirow{3}{*}{ 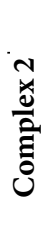 } & 408 & 397.68 & 3.11 & 0.16 & $\mathrm{H} \rightarrow \mathrm{L}(89.21 \%)$ & ILCT \\
\hline & \multirow[b]{2}{*}{324} & 321.59 & 3.85 & 0.08 & $\mathrm{H} \rightarrow \mathrm{L}+2(82.06 \%)$ & LMCT \\
\hline & & 310.87 & 3.98 & 0.01 & $\begin{array}{c}\mathrm{H}-6 \rightarrow \mathrm{L}(39.14 \%) \\
\mathrm{H}-4 \rightarrow \mathrm{L}(17 \%) \\
\mathrm{H}-6 \rightarrow \mathrm{L}+1(10.13 \%)\end{array}$ & $\begin{array}{l}\text { LMCT/LLCT/ILCT } \\
\text { LMCT/LLCT/ILCT } \\
\text { LMCT/LLCT/ILCT }\end{array}$ \\
\hline
\end{tabular}




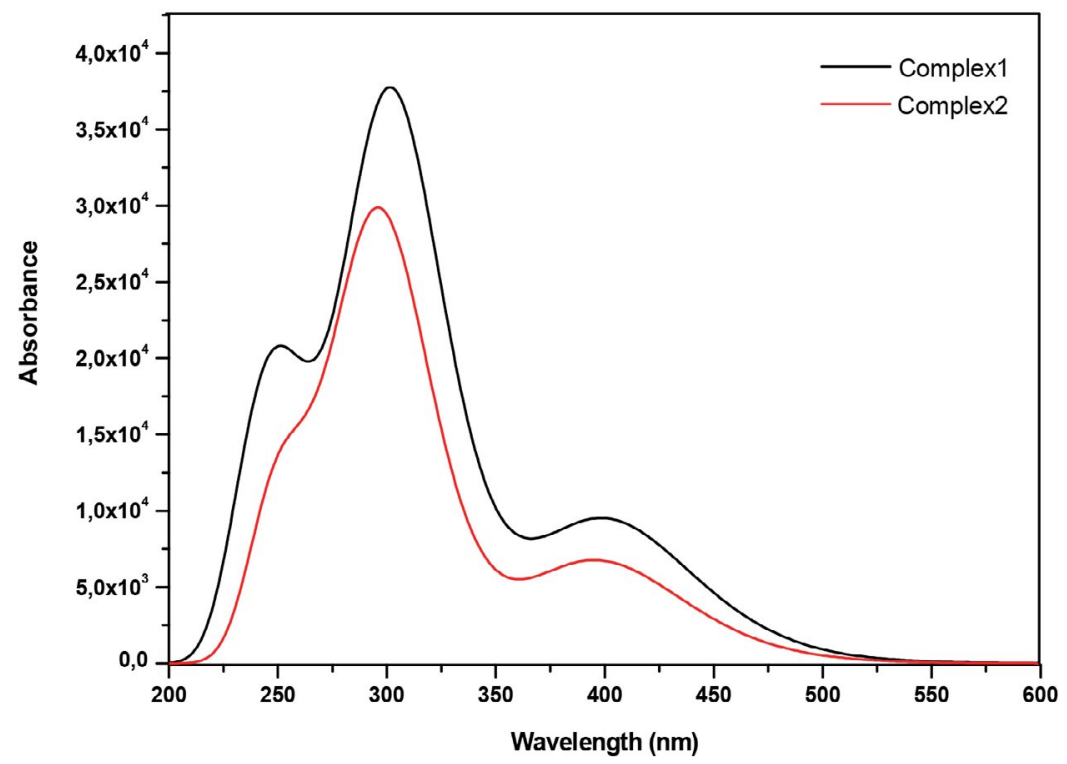

Figure 3. The theoretical UV-Vis spectra for two Mo complexes.

Time-dependent density functional theory (TDDFT) calculations combined with CAM-B3LYP method have been performed in liquid phase to investigate the absorption properties of the two Mo complexes. The calculated absorption parameters with experimental data are listed in Table 3. The UV spectrum of complex 1 monitored in Figure 3 shows four bands located at 402.34, $323.36,311.12$ and $301.30 \mathrm{~nm}$. The important contributions of orbitals in different transitions reported in table 3 attribute these bands respectively to $\mathrm{HOMO} \rightarrow$ LUMO, $\mathrm{HOMO} \rightarrow \mathrm{LUMO}+1, \mathrm{HOMO}-1 \rightarrow \mathrm{LUMO}$, and $\mathrm{HOMO} \rightarrow$ LUMO+2due to $\pi\left(\mathrm{H}_{2} \mathrm{~L}\right) \rightarrow \mathrm{d}$ (Mo) charge transfer (LMCT) mixed with both $\pi \rightarrow \pi^{*}$ and $n \rightarrow \pi^{*}$ transitions (ILCT/ LLCT). Regarding the UV spectrum of complex 2 (Figure
3), two principal bands were observed at 397.68 and 321.59 $\mathrm{nm}$ attributed to $\pi\left(\mathrm{H}_{2} \mathrm{~L}\right) \rightarrow \mathrm{d}(\mathrm{Mo})$ charge transfer (LMCT). The decrease detected in the absorption intensity gives a hypochromic effect. It's due to the substitution of the ligand.

\section{4. Solvent Effect on Absorption Properties}

TD-DFT calculations have been performed in order to predict the effect of different solvents on absorption properties in the UV range of complex1. Figure 4 are illustrate maximum absorption bands $\left(\lambda_{\max }\right)$ in the obtained spectra of the studied compound in vacuum and in differ-

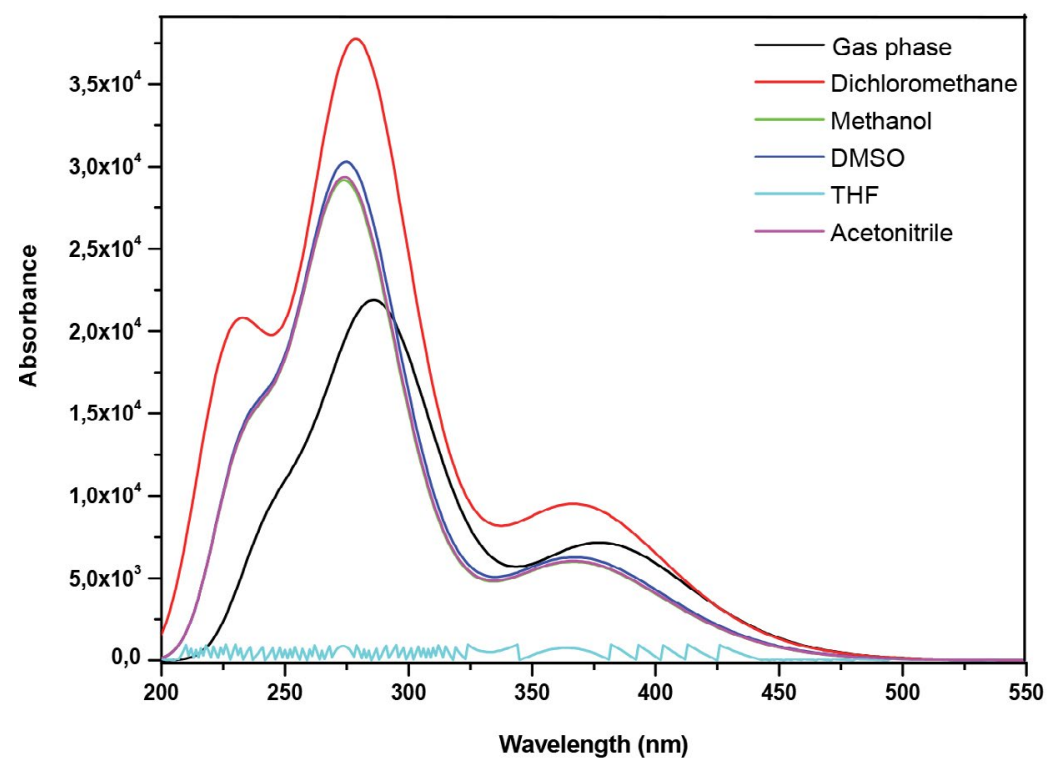

Figure 4. The theoretical UV-Vis spectra for complex1 in different solvents 
ent solvents: dichloromethane $\left(\mathrm{CH}_{2} \mathrm{Cl}_{2}\right)$, methanol $\left(\mathrm{CH}_{2} \mathrm{OH}\right)$, dimethyl sulfoxide DMSO $\left(\mathrm{C}_{2} \mathrm{H}_{6} \mathrm{OS}\right)$, tetrahydrofuran THF $\left(\left(\mathrm{CH}_{2}\right)_{4} \mathrm{O}\right)$ and acetonitrile $\left(\mathrm{CH}_{3} \mathrm{CN}\right)$. It can be seen that the complex 1 exhibits tow bands of maximum absorption between 400 and $225 \mathrm{~nm}$ for all solutions and the spectra look the same. The decrease in absorption intensity indicates that the used solvents have simultaneously hypochromic effect on the absorption properties of the examined compound. Compared to those of complex 1 in vacuum the absorption shift to a longer wavelength (red shift) indicates that bathochromic shift is observed. Similar trends are observed in DMSO, methanol and acetonitrile solvents but with lower band intensities compared to dichloromethane. In the case of THF, no band appeared, indicating that the tested complex dissolved in THF does not exhibit typical absorption bands in UV range.

\section{5. Infrared Spectra}

Fourier transferred infrared spectroscopy analysis is mainly used to identify the functional groups in the molecules. In the case of our study, vibrational frequency calculations $s^{39,40}$ were performed at the same theoretical level to compare between the calculated IR spectrum of the complex 1 and the experimental one. The absence of imaginary frequencies in the calculated vibrational modes indicates that the obtained optimized geometry corresponds to a minimum on the potential energy surface. The theoretical infrared spectra of the complex 1 and its ligand are shown in Figure 5 and 6 respectively. The experimental and theoretical vibrational wavenumbers and intensities for the complex 1 and the ligand are reported in Table 4. The com- parison of the results displayed reveals that the experimental and the theoretical values of the vibrational wavenumbers are approximately close.

Regarding the IR signals of the ligand, tow intense bands are observed at 1672.30 and $1765.66 \mathrm{~cm}^{-1}$ corresponding to $v(\mathrm{C}=\mathrm{O})$ and $v(\mathrm{C}=\mathrm{N})$ stretching of the imine group, ${ }^{41}$ respectively. Thin bands were observed in the range of 3160-3360 $\mathrm{cm}^{-1}$, assigned to the presence of hydrogen bonded $v(\mathrm{NH})$ and $v(\mathrm{OH}){ }^{42,43}$ The existence of the above bands confirms that the ligand of the studied compound is a Schiff base with a hydroxyl substituent.

As represented in Figure 5 and reported in Table 4, the dioxidomolybdenum (VI) complex with a cis $\mathrm{MoO}_{2}$ part has two strong bands at 987.75 and $1023.18 \mathrm{~cm}^{-1}$, assigned to a symmetrical and asymmetrical $v(\mathrm{O}-\mathrm{M}-\mathrm{O})$ vibrations respectively. ${ }^{44,45}$

The absence of NH vibration in IR spectra of the complex indicates that a nitrogen atom $\mathrm{N}$ coordinates $\mathrm{Mo}$ center by the free lone electron pair.

Table 4. The experimental and theoretical vibrational wavenumbers and intensities for the ligand and its Mo (VI) complex.

\begin{tabular}{lcc}
\hline & \multicolumn{2}{c}{ FTIR freq $\left(\mathbf{c m}^{-\mathbf{1}}\right)$} \\
Assignments & $\operatorname{Exp}^{\mathbf{2 4}}$ & $\mathbf{C a l}$ \\
\hline $\boldsymbol{v}\left(\mathbf{H}_{\mathbf{2}} \mathbf{O}\right)$ & 3512 & 3794.93 \\
$\boldsymbol{v}(\mathbf{O H})$ & 3300 & 3834.65 \\
$\boldsymbol{v}(\mathbf{C N})$ & 1614 & 1633.91 \\
$\boldsymbol{v}\left(\mathbf{N}_{2}\right)$ & 1132 & 1097.66 \\
$\boldsymbol{v}(\mathbf{C O})$ & 1240 & 1248.9 \\
$\boldsymbol{v}(\mathbf{M O})$ & 565 & 594.12 \\
$\boldsymbol{v}(\mathbf{M N})$ & 441 & 382.05 \\
$\boldsymbol{v}\left(\mathbf{M O}_{2}\right)$ & 946 & 1023.18 \\
\hline
\end{tabular}

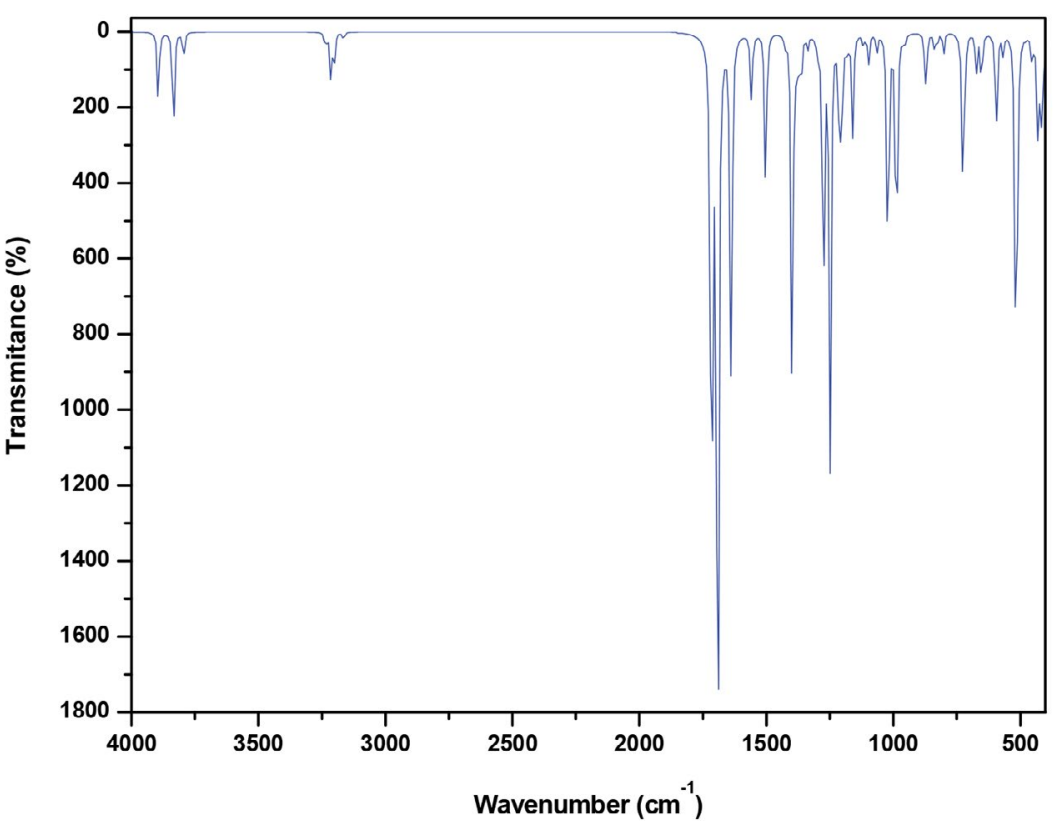

Figure 5. Theoretical IR spectra for complex 1 


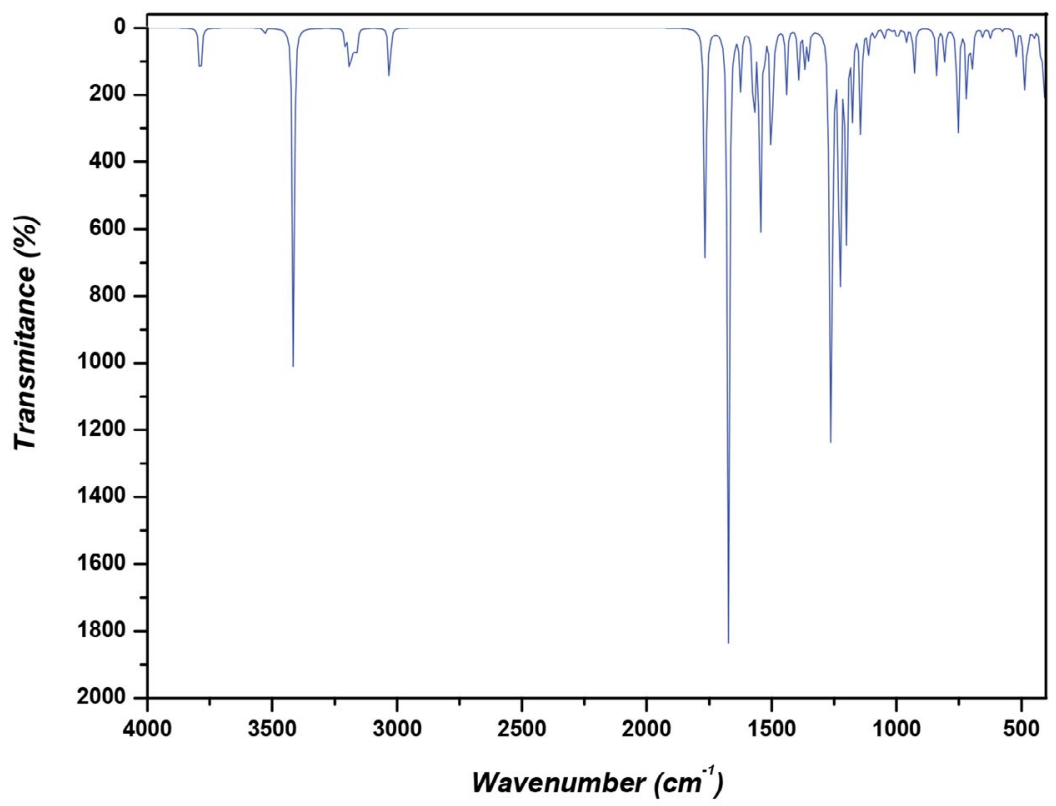

Figure 6. Theoretical IR spectra for ligand

\section{Conclusion}

In this paper, we investigated the structural parameters, electronic structures and spectroscopic properties of two cis-dioxomolybdenum (VI) complexes using DFT and TDDFT calculations. The optimized geometries in the ground state show that the structural parameters are in agreement with the experimental values. The predominant transitions are governed by a ligand-metal charge transfer (LMCT) due to the electronic configuration of the metal atom Mo (VI) in the complex, which is equal to zero $\left(\mathrm{d}^{0}\right)$, therefore, the d-d excited state is unavailable usually referred as metal-centered (MC) transition. UV-Vis spectra of complex 1 calculated in gas and in liquid phase solvents show a decrease in absorption intensity indicating that the used solvents have simultaneously hypochromic effect on the absorption properties. The complex dissolved in THF does not exhibit typical absorption bands in UV range. According to IR spectra, the observed bands confirm that the ligand of the studied compound is a Schiff base with a hydroxyl substituent. The disappearance of $\mathrm{NH}$ vibration indicates that the nitrogen atom $\mathrm{N}$ coordinates Mo center by the free lone electron.

\section{Acknowledgments}

The authors wish to thank Professor Henry Chermette (Institute of Analytical Sciences, UMR 5280, Lyon, FRANCE) for technical support, for its fruitful discussion and for the careful proofreading of the article.

Conflict of interest: The authors declare that they have no conflict of interest.

\section{Supporting Information Available}

Selected theoretical geometric parameters of complex 2 are reported in Table $\mathrm{S} 1$ and the Frontier molecular orbitals (FMO) of Mo complexes are given in Figure S1.

\section{References}

1. C. J. Windorff, G. P. Chen, J. N. Cross, W. J. Evans, F. Furche, A. J. Gaunt, M. T. Janicke, S. A. Kozimor and B. L. Scott, Journal of the American Chemical Society. 2017, 139, 3970-3973. DOI:10.1021/jacs.7b00706

2. S. Sangeeta, K. Ahmad, N. Noorussabah, S. Bharti, M. K. Mishra, S. R. Sharma and M. Choudhary, Journal of Molecular Structure. 2018, 1156, 1-11.

DOI:10.1016/j.molstruc.2017.11.062

3. O. V. Nesterova, D. S. Nesterov, A. Krogul-Sobczak, M. F. C. Guedes da Silva and A. J. L. Pombeiro, Journal of Molecular Catalysis A: Chemical. 2017, 426, 506-515.

DOI:10.1016/j.molcata.2016.09.005

4. K. S. Kumar, S. Ganguly, R. Veerasamy and E. De Clercq, European journal of medicinal chemistry. 2010, 45, 5474-5479. DOI:10.1016/j.ejmech.2010.07.058

5. I. Sheikhshoaie, S. Y. Ebrahimipour, M. Sheikhshoaie, H. A. Rudbari, M. Khaleghi and G. Bruno, Spectrochimica Acta Part A: Molecular and Biomolecular Spectroscopy. 2014, 124, 548555. DOI:10.1016/j.saa.2014.01.043

6. H. M. Mehdi, Z. Niklas, G. Golara, B. Ferdinand, B. Mojtaba, S. J. A. and M.-Z. N. C., European Journal of Inorganic Chemistry. 2018, 2018, 2549-2556.

7. S. Y. Ebrahimipour, M. Khosravan, J. White and S. Fekri, Applied Organometallic Chemistry. 2018, 32, 1-11.

DOI:10.1002/aoc.4233 
8. S. P. Sovilj, D. Mitić, B. J. Drakulić and M. Milenković, Journal of the Serbian Chemical Society. 2012, 77, 53-66. DOI:10.2298/JSC110328160S

9. S. Pasayat, S. P. Dash, P. K. Majhi, Y. P. Patil, M. Nethaji, H. R. Dash, S. Das and R. Dinda, Polyhedron. 2012, 38, 198-204. DOI:10.1016/j.poly.2012.03.007

10. G. L. Parrilha, R. P. Vieira, A. P. Rebolledo, I. C. Mendes, L. M. Lima, E. J. Barreiro, O. E. Piro, E. E. Castellano and H. Beraldo, Polyhedron. 2011, 30, 1891-1898.

DOI:10.1016/j.poly.2011.04.024

11. W.-J. Shin, J.-Y. Lee, J. C. Kim, T.-H. Yoon, T.-S. Kim and O.K. Song, Organic Electronics. 2008, 9, 333-338. DOI:10.1016/j.orgel.2007.12.001

12. L. H. Abdel-Rahman, N. M. Ismail, M. Ismael, A. M. Abu-Dief and E. A.-H. Ahmed, Journal of Molecular Structure. 2017, 1134, 851-862. DOI:10.1016/j.molstruc.2017.01.036

13. R. N. Egekenze, Y. Gultneh and R. Butcher,Inorganica Chimica Acta. 2018, 478, 232-342.

DOI:10.1016/j.ica.2018.01.027

14. D. Majumdar, J. K. Biswas, M. Mondal, M. S. Babu, R. K. Metre, S. Das, K. Bankura and D. Mishra, Journal of Molecular Structure. 2018, 1155, 745-757.

DOI:10.1016/j.molstruc.2017.11.052

15. Ö. Şahin, Ü. Ö. Özdemir, N. Seferoğlu, Z. K. Genc, K. Kaya, B. Aydıner, S. Tekin and Z. Seferoğlu, Journal of Photochemistry and Photobiology B: Biology. 2018, 178, 428-439.

DOI:10.1016/j.jphotobiol.2017.11.030

16. M. Chakraborty, S. Roychowdhury, N. R. Pramanik, T. K. Raychaudhuri, T. K. Mondal, S. Kundu, M. G. Drew, S. Ghosh and S. S. Mandal, Polyhedron. 2013, 50, 602-611.

DOI:10.1016/j.poly.2012.12.006

17. J. M. Mir, S. Roy, P. K. Vishwakarma and R. C. Maurya, Journal of the Chinese Advanced Materials Society. 2018,6, 1-19.

18. A. Magalon, J. G. Fedor, A. Walburger and J. H. Weiner, Coordination chemistry reviews. 2011, 255, 1159-1178.

DOI:10.1016/j.ccr.2010.12.031

19. C. J. Doonan, H. L. Wilson, K. Rajagopalan, R. M. Garrett, B. Bennett, R. C. Prince and G. N. George, Journal of the American Chemical Society. 2007, 129, 9421-9428.

DOI:10.1021/ja071402a

20. S. Rayati, N. Rafiee and A. Wojtczak,Inorganica Chimica Acta.2012, 386, 27-35. DOI:10.1016/j.ica.2012.02.005

21. K. R. Jain, W. A. Herrmann and F. E. Kühn, Coordination Chemistry Reviews. 2008, 252, 556-568.

DOI:10.1016/j.ccr.2007.10.018

22. A. Rezaeifard, M. Jafarpour, H. Raissi, M. Alipour and H. Stoeckli-Evans, Zeitschrift für anorganische und allgemeine Chemie. 2012, 638, 1023-1030.

DOI:10.1002/zaac.201200079

23. R. G. Parr: Horizons of Quantum Chemistry, Springer, 1980, pp. 5-15.

24. S. A. Aboafia, S. A. Elsayed, A. K. El-Sayed and A. M. El-Hen- dawy, Journal of Molecular Structure. 2018, 1158, 39-50.

DOI:10.1016/j.molstruc.2018.01.008

25. P. Hohenberg, Phys. Rev.1964, 136, B864. DOI:10.1103/PhysRev.136.B864

26. C. Lee, W. Yang and R. G. Parr, Physical review B. 1988, 37, 785. DOI:10.1103/PhysRevB.37.785

27. X.-W. Fan, X.-H. Ju and H.-M. Xiao, Journal of hazardous materials. 2008, 156, 342-347.

DOI:10.1016/j.jhazmat.2007.12.024

28. T. Wei, W. Zhu, J. Zhang and H. Xiao, Journal of hazardous materials. 2010, 179, 581-590.

29. T. Yanai, D. P. Tew and N. C. Handy, Chemical Physics Letters. 2004, 393, 51-57. DOI:10.1016/j.cplett.2004.06.011

30. P. J. Hay and W. R. Wadt, The Journal of chemical physics. 1985, 82, 270-283. DOI:10.1063/1.448799

31. P. J. Hay and W. R. Wadt, The Journal of Chemical Physics. 1985, 82, 299-310. DOI:10.1063/1.448975

32. A. Petersson, A. Bennett, T. G. Tensfeldt, M. A. Al-Laham, W. A. Shirley and J. Mantzaris, The Journal of chemical physics. 1988, 89, 2193-2218. DOI:10.1063/1.455064

33. W. J. Hehre, R. Ditchfield and J. A. Pople, The Journal of Chemical Physics. 1972, 56, 2257-2261.

DOI:10.1063/1.1677527

34. T. Helgaker and P. Jørgensen, The Journal of chemical physics. 1991, 95, 2595-2601. DOI:10.1063/1.460912

35. E. Cances, B. Mennucci and J. Tomasi, The Journal of chemical physics. 1997, 107, 3032-3041. DOI:10.1063/1.474659

36. R. A. Gaussian09, Inc., Wallingford CT2009.

37. K. Fukui, T. Yonezawa and H. Shingu, The Journal of Chemical Physics. 1952, 20, 722-725. DOI:10.1063/1.1700523

38. K. Fukui, T. Yonezawa, C. Nagata and H. Shingu, The Journal of Chemical Physics.1954, 22, 1433-1442.

DOI:10.1063/1.1740412

39. F. Perakis, L. De Marco, A. Shalit, F. Tang, Z. R. Kann, T. D. Kühne, R. Torre, M. Bonn and Y. Nagata, Chemical reviews.2016, 116, 7590-7607.

DOI:10.1021/acs.chemrev.5b00640

40. D. Ojha, K. Karhan and T. D. Kühne, Scientific reports.2018, 8, 16888. DOI:10.1038/s41598-018-35357-9

41. M. Ocak, T. Ak, A. Aktaş, N. Özbek, O. C. Çağılcı, A. Gümrükçüoğlu, H. Kantekin, Ü. Ocak and H. Alp, Journal of fluorescence. 2017, 27, 59-68. DOI:10.1007/s10895-016-1934-9

42. Y. Tan, N. Zhao, J. Liu, P. Li, C. N. Stedwell, L. Yu and N. C. Polfer, Journal of The American Society for Mass Spectrometry. 2017, 28, 539-550. DOI:10.1007/s13361-016-1575-x

43. S. T. El-Sayed, A. M. Ali, E. El-Sayed, W. G. Shousha and N. I. Omar, J. Appl. Pharm. Sci. 2017, 7, 6-12.

44. R. Takjoo, A. Hashemzadeh, H. A. Rudbari and F. Nicolo, Journal of Coordination chemistry. 2013, 66, 345-357.

DOI:10.1080/00958972.2012.748191

45. N. Maheswari and G. Muralidharan, Applied Surface Science. 2017, 416, 461-469. DOI:10.1016/j.apsusc.2017.04.094 


\section{Povzetek}

V tem prispevku smo z uporabo računskih tehnik opredelili dva enojedrna molibdenova kompleksa s Schiffovo bazo $\mathrm{H}_{2} \mathrm{~L}$ tridentatnim (ONO) ligandom. Teorija gostotnega funkcionala (DFT) in njeni časovno podaljšani (TD-DFT) izračuni so bili izvedeni v namen preučevanja elektronske strukture osnovnega in vzbujenega stanja ter za interpretacijo elektronskih absorpcijskih spektrov v plinski in vodni fazi. Izračuni TDDFT potrjujejo, da je LMCT prenos naboja prevladujoč za oba kompleksa. Opazili smo hipokromni učinek na absorpcijske lastnosti glede na substitucijo topila. Vsi teoretični rezultati se dobro ujemajo $\mathrm{z}$ razpoložljivimi eksperimentalnimi podatki 